\title{
Historein
}

Vol 9 (2009)

Historising: 1968 and the Long Sixties

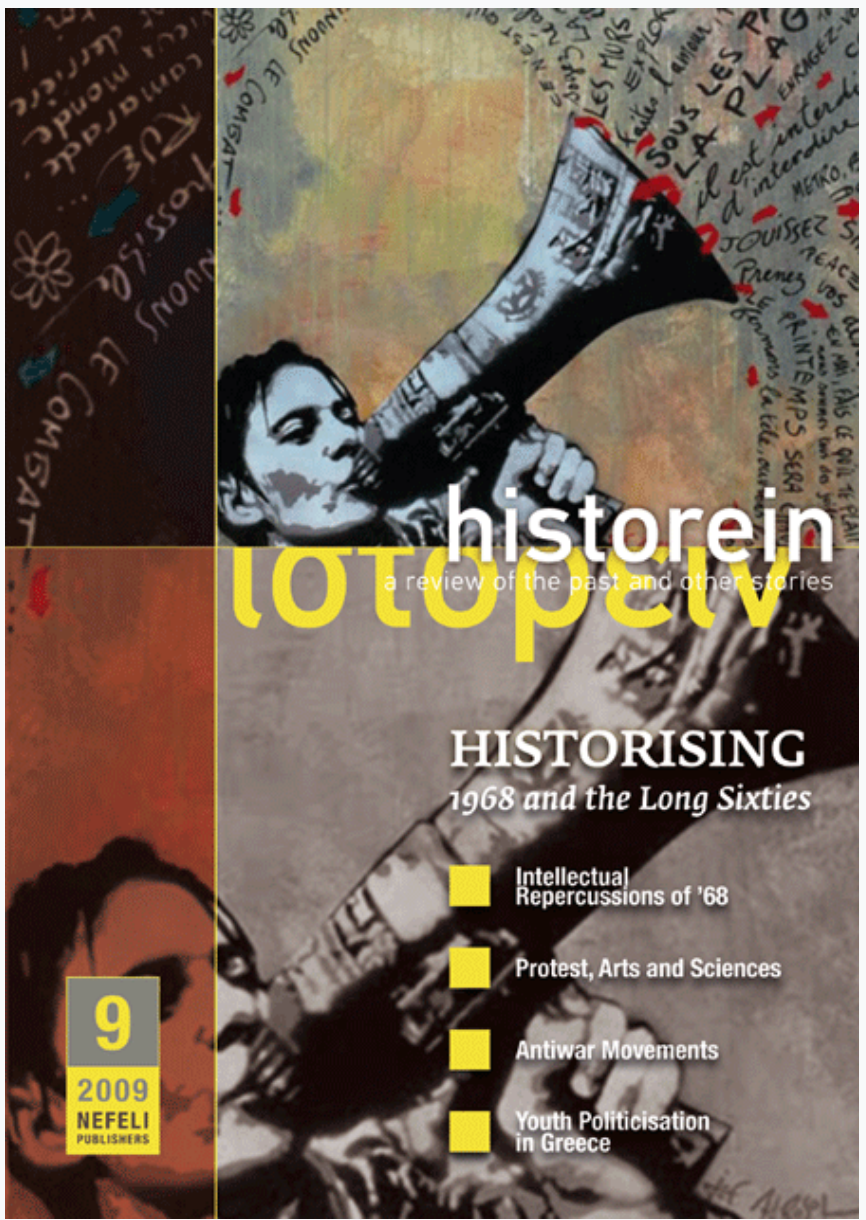

Art Movements in the 1960 s and the Debate about Modernity

Angeliki Koufou

doi: $10.12681 /$ historein.28

Copyright @ 2012, Angeliki Koufou

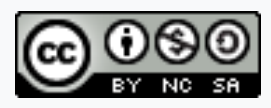

This work is licensed under a Creative Commons Attribution-NonCommercialShareAlike 4.0.

To cite this article:

Koufou, A. (2010). Art Movements in the 1960s and the Debate about Modernity. Historein, 9, 140-148. https://doi.org/10.12681/historein.28 


\section{Art Movements in the 1960s and the Debate about Modernity}

\section{Angeliki Koufou}

The rise of the student movement in the 1960s, which broadened its criticism of the educational system to include society and institutions, brought about an artistic avant-garde, which appropriated the pop culture of a generation in revolt. This generation challenged the hegemony of institutionalised art and sought liberation from normative social premises. Pop became the symbol of a new lifestyle legitimised through the struggle against conservative high culture and it stood for a variety of sub- or underground cultures. Through the form of happenings, the pop vernacular, psychedelic art, acid rock, alternative and street theatre, the pop avant-garde was deployed in a culture of confrontation, which provided the foundation for the rise of the New Left. A constellation of countercultures, embracing iconoclastic gestures and habits in everyday life, converged with the New Left to attack established cultural institutions, authoritarianism and bureaucratic rationalism. Although many thinkers insist on its local particularities, this movement, which was linked to the students' movements and riots, was a global, transnational, subversive protest against the conformism of modernist culture and the institutionalisation of art.

The characteristic features of this new movement - a sense of rupture and discontinuity, the creative imagination together with a technological euphoria and an emphasis on the emancipatory, utopian role of art - are reminiscent of the historical avant-garde of the beginning of the twentieth century, according to Andreas Huyssen. ${ }^{1}$ The similarity between the two move- 
ments can be shown in their common demand for the need of reintegrating art into the praxis of life, and for the endorsement of a new aesthetics contributing to the transformation of everyday life. ${ }^{2}$ In addition, both movements were strongly politicised as their artistic activities overlapped with antiauthoritarian struggles. The neo avant-garde of the 1960s seems to have pursued the same goals as the historical avant-garde, which attempted to attack, undermine and transform the bourgeois 'institution art' and its ideology of autonomy. ${ }^{3}$ Strong references to Dada and surrealism as well as the revival of its leading figures such as Marcel Duchamp and René Magritte prove the affinities of the challenging artistic and cultural agenda of the 1960s avant-garde with the historical avant-garde. ${ }^{4}$ However, the gradual fading, exhaustion and assimilation of part of both avant-garde movements into the commodified market instigated new debates focusing on the issue of modernity. More specifically, the reaffirmation of the subversive role of art and the collapse of revolutionary utopia due to its failure to merge art and life led to the need to investigate the nature and limits of modernity itself. The main issues stemming from this reassessment are linked - as we shall see - to the end of aesthetic modernism as well as the range and viability of the so-called Enlightenment project as the bedrock of human emancipation.

Let us begin with the study of the topography of the neo-avant-garde phenomenon, which is crucial for its understanding. Although this mainly cultural revolution had a vast range, it was not homogenous. The divergence in the neo-avant-garde movement in the 1960s is associated with the different reception and role of high modernism and the avant-garde in the 1920s in Europe and the United States respectively. ${ }^{5}$ The differences and not the similarities between the two movements (modernism and the avant-garde), both of which denounced capitalist alienation and reacted to rapid industrialisation and the new conditions of production and consumption, defined to a great extent the debate in so far as their function and perception are inextricably linked to the philosophical and political grounding of explaining modernity. The mid-nineteenth century crisis of realistic representation was gradually connected to the rise of aesthetic modernism and the autonomy of art. ${ }^{6}$ The demand for autonomy stemmed from the realisation of the non-reconcilability of aesthetic aspiration and social reality, since the belief that art gave a 'promesse de bonheur' was eradicated from the continued separation of production and consumption in an unfree society. Thus, the demand for autonomous art and aesthetic experience as a protection against capitalist reification would disturb the harmonious balance of the three spheres of reason - science, art and morality - as it was formulated by Enlightenment philosophers. In modernist work of art, fragmentation and abstraction stands for protest in a disenchanted world, as Adorno persuasively argued in his Aesthetic Theory. However, the ascetic hermetism of high modernism was criticised by the avant-garde movements in relation to the social function of art and its merging with the praxis of life. Peter Bürger argues that the politics of the avant-gardistes were founded on the sublation of art, in the Hegelian sense (Aufhebung). ${ }^{8}$ Nevertheless, the change in the role of art is linked to the transformation of the praxis of life in the capitalist world on the basis of new values. In this sense aestheticism, as an extreme version of autonomy, and the avant-garde have something in common: they both rejected the means-ends rationality of bourgeois everyday life. Aestheticism abandoned the prospect of social transformation and attempted to preserve the authenticity of the aesthetic experience by endorsing the autonomy of art. On the other hand, the avant-garde aspired to social subversion through art. What distinguishes them, then, is that the latter sought to reorganise new life praxes from a basis in art. 
Aestheticism, as Peter Bürger claims, became a necessary prerequisite for the manifestation of the avant-garde movement. ${ }^{\text {? }}$

In Europe, the avant-garde of the 1920s (Dada, surrealism, Russian futurism) had deep roots, whereas in the US the 'high art' of modernism struggled hard to gain wider legitimacy, and Dada and surrealism remained, in the best of cases, a marginal phenomenon without indigenous production. The iconoclastic and anti-aesthetic ethos of the avant-garde, which challenged the traditional concepts of beauty, creativity and originality, repelled many of the major American writers such as Henry James, William Faulkner and T. S. Elliot, who sought their expression in the autonomous sensibility of modernism, which insisted on the dignity and autonomy of literature. ${ }^{10}$ This is the reason why 40 years later the avant-garde of the 1960s in America displayed a powerful sense of the future, new frontiers and a break with the past. The impetuous invasion of this neo-avant-gardist movement came as a reaction to the predominance of academic modernism in the postwar period. The exhaustion of the revolutionary potential of 'heroic' modernism of the interwar period politically led to Cold War anticommunism and aesthetically to an institutionalised and domesticated version of modernism articulated in the ossified artistic doctrine of New Criticism." According to David Harvey, this was the end of "positivistic, technocentric and rationalistic" modernism, which was based on a strong belief in "linear progress, absolute truths and rational planning of ideal social orders".12 As Harvey argues, the depoliticisation of modernism presaged its embrace by the political and cultural establishment as an ideological weapon in the Cold War. Modernist values were assimilated, utilised and co-opted by politicians. ${ }^{13}$ Thus, the neo-avantgarde was reacting against this form of modernism and sought to recapture the lost adversary ethos which had stimulated modern art. The valorisation of the populist trend celebrating the imagery of everyday life and the multiple forms of popular literature, which became an integral component of the neo-avant-garde, is described by Leslie Fiedler as postmodern. Fiedler in his essay "The New Mutants" speaks about a "post-white", "post-male", "post-humanist", "post-puritan" world, reintroducing the rivalry between high art and pop culture. In his text one can trace the seeds of the political critique of what was later called eurocentrism and logocentrism. ${ }^{1.4}$ The conceptualisation and use of the term 'postmodern' are symptomatic of the developments in the spheres of theory and culture, which mark the beginning of a cultural transformation, perceived as a shift in sensibility, in Western societies. This transformation in discourses and practices has generated a debate concerning the nature, range and limits of modernity. In the 1960s movements one can trace the origins of the formation of an extremely heterogeneous grid of elaborations ranging from the artistic to cultural and theoretical production, which is usually described by the generalising term 'postmodernism'. ${ }^{15}$ However, instead of analysing the contradictory and fragmented nature of modernity and its inherent tensions, many theorists tended to juxtapose this multifarious and heterogeneous cultural production, which they lumped under the term postmodern, with a 'healthy' homogenised modernism deriving from a modernity threatened by a politically incorrect and morally irresponsible postmodernism. ${ }^{16}$ Although this issue is crucial, this article will not dwell on this debate in general but will focus on its epistemological and political repercussions from the perspective of the development of modern art movements.

The idea of modernity, as Jürgen Habermas suggests in his article "Modernity versus Postmodernity", "is intimately tied" to the development of European art. ${ }^{17}$ Habermas elaborates a specific 
narrative of modernity. It is the project of enlightened modernity, the one that associates modernity with the Enlightenment project as the basis for the rational development of society envisaging human emancipation. Re-examining Weber's scheme, Habermas thinks that the project of modernity would be completed with the parallel development of the three spheres - science, morality and art - corresponding respectively to truth, normative rightness and beauty. ${ }^{18}$ The parallel and balanced development of the three spheres in their respective inherent logic is considered by Habermas as a necessary prerequisite for a rational organisation and enrichment of everyday social life. ${ }^{19}$ However, the aesthetic content Habermas attributes to the term 'modern' distances him from the developments in the field of art and the subversive rise of aesthetic modernism. His notion of the modern alludes to the concept of the classical with which the modern "preserves a secret tie". ${ }^{20}$ It also stems from a normalising perception of historical continuum, where the modernist revolution expressed via the exaltation of the present and the rupture with the past is criticised as undermining the Enlightenment project.

Habermas blames aesthetic modernism for detaching art from life, abandoning reconciliation and aspiring to the autonomy of art. Nevertheless, he is even more hostile towards the revolutionary avant-garde of the beginning of the century, despite the fact that this artistic movement attempted to reintegrate art into life, breaking thus the links to high modernism. As Peter Bürger argues, the sublation claim (Aufhebungsansprüche) could never work because of the structural differences between the three spheres mentioned above. Bürger focuses on what the Weberian model conceals. He considers the primacy of science as the central problem within the modernisation process and traces the origins of the failure of the modernity project in the disproportionate development of this sphere. ${ }^{21}$ Habermas' endorsement of a harmonious ideal scheme that was never realised stems from a unifying perception of modernity, which erases its conflictual nature and underrates the dialectical understanding of ruptures. In this context Habermas imputes to the avant-garde "the anarchistic intention of blowing up the continuum of history", the annulment of historical memory and, finally, associates it with the "extremes of history". ${ }^{22}$ By refusing to consider the differences between the avant-garde and high modernism, Habermas lumps them together under cultural irrationalism without acknowledging their contribution to modernist utopias. Habermas' defence of enlightened modernity flows from the Nazi experience, which he considers as an irrationalist deviation due to the hypertrophic development of aesthetics. Thus, the fulfilment of the Enlightenment project, which still remains incomplete, is identified with the defence of political democracy.

Elaborating his views further, Habermas traces the continuity between the surrealists and the neo-avant-garde of the 1960s and 1970s, associating them both with what he calls "the negation of culture". However, the avant-garde and post- or neo-avant-garde both challenged the logocentric paradigm of interpreting the world. Habermas describes the constellation of these movements as "an emotional current of our times, which has penetrated all spheres of intellectual life", and situates them in an era of postmodernity, "which presents itself, as Antimodernity". ${ }^{23} \mathrm{He}$ was the first, but not the last, ${ }^{24}$ to present these movements as the cultural and political harbinger of what would come to be called postmodernism, which he considers as a threat to the cultural and political program of enlightened modernity. However, he somehow contradicts himself since he too had already traced the seeds of the abandonment of the project of the 
enlightened modernity within modernity itself. By rejecting aesthetic modernism as well as the philosophical and political context of its articulation, Habermas embraces a version of modernity as an undifferentiated continuum, purged of its nihilistic and anarchic elements, whereas at the same time he advocates an outmoded, idealistic aesthetic doctrine. It has to be mentioned that the recognition of an elective affinity or continuity between the avant-garde of the 1920s and the post-avant-garde of the 1960s undermines the binary opposition he attempted to introduce between "healthy" modernity and "threatening" postmodernity, to the extent that, according to his analysis, modernity carries within itself the seeds of dissolution of the Enlightenment project. The evolutionary scheme that Habermas adopts disregards the contribution of revolutionary movements to the formation of modernity and corresponds to a "domesticated" version of Marxism, whereas at the same time it diverges from the legacy of the Frankfurt School. ${ }^{25}$ Nevertheless, his thought influenced many Marxist thinkers and contributed to establishing a Marxistenlightened paradigm, which was completed in the 1970 s. ${ }^{26}$

An opposite version of modernity is based on a critical reading of the Enlightenment narrative and the logocentric programme of dominating nature which it inaugurated. This version is organised around the understanding of aesthetic modernism as a literary, artistic as well as politically subversive movement launched against capitalist modernisation which is linked with Enlightenment dynamics. This reading - whose origins can be traced to Max Horkheimer and Theodor Adorno's work - exalts the contribution of the avant-garde and of artistic experimentation in challenging the establishment and in revolutionalising society. Preserving the subversive and experimental character of art from the art market and the determining aesthetic norms is of great importance, according to Jean-François Lyotard, who associated modernism with the withdrawal of realistic representation in art and the confrontation of the presentable with the conceivable expressed by the notion of the 'sublime'. Lyotard argued that the aesthetics of the sublime are intimately connected to the emergence of modern art, which, according to him, "devotes its 'little technical expertise' to present the fact that the unpresentable exists". Juxtaposing the aesthetic of the sublime with that of the beautiful, he detaches the aesthetic experience from the totalising supremacy of cognitive faculties. The sentiment of the sublime expressing disarray imparts no knowledge about reality. Consequently, it prevents the stabilisation of taste and the unification of the three spheres - science, morality, art - which gives rise to the sentiment of the beautiful. Rejecting the "illusion of unity", Lyotard, in complete contrast to Habermas, combats not only the suspension of artistic experimentation but also the "idea of a unitary end of history and of a subject", leading, as he maintains, to terror. ${ }^{27}$ Thus, the embodiment of the objective mind in works of art, aiming at what Habermas called "the rationalisation of everyday life", is a step in this direction. ${ }^{28}$ Lyotard insisted that the notion of the sublime widens the limits of imagination and aesthetic aspiration allowing the renewal of artistic creation while, at the same time, salvages the utopian and anarchic impulse..$^{29}$ The quest for a perpetual transcendence of the aesthetic expression links the avant-garde of the 1920s with that of the 1960s, which stands for the revival and transcendence of the modern, as "post-modern", in the sense that Lyotard attributes to the term. ${ }^{30}$

At this point we must return to the criticism of both modernism and the avant-garde concerning their failure to achieve their respective goals. The transformation of high modernism into a 
powerful institution, on the one hand, and the absorption of a large part of the avant-garde by the commodity culture, on the other, led to their depoliticisation and the annulment of the utopian hope for a social transformation through art. Some thinkers identified this expectation with the sublation claim. However, the sublation claim and utopian hope must not be construed as identical: even if it aims at preserving the subversive character of art, the use of the sublation claim in the context of modernity and late modernity becomes rather problematic. The sublation claim (Aufhebungsanspruch), which is a romantic claim, as Hegel elaborated it, cannot correspond to the restlessness and instability of the modernist era as well as to the sense of anarchy, disorder and despair expressed through modernism. Thus, modern art sought its way in a break with aesthetic tradition through "mimetic adaptation of what is hardened and alienated". ${ }^{31} \mathrm{Grad}-$ ually, reconciliation claims via art were abandoned, since modern art, according to Adorno, denies the possibility of happiness. The way Marxists such as Peter Bürger embrace the sublation claim reveals the indebtedness of the majority of them to idealism and Hegelianism. Moreover, the sublation claim alludes to totality, a notion which was abandoned by Critical Theory and denounced by Adorno as a synonym for totalitarianism. ${ }^{32}$ In addition, the category of totality, which presupposes the very notion of a meta-subject capable of totalising reality, draws directly on the idealistic notion of a transcendental subject. ${ }^{33}$ Although Critical Theory and Adorno in particular strongly criticised and almost demolished Western Marxism's initial concept of normative totality, this continued to be a major component of the Marxist narrative as it was re-established by Habermas. ${ }^{34}$ Bürger's approach to the avant-garde as an attempt to reintegrate art into the praxis of life is imbued with an aspiration to totality. ${ }^{35}$ The desire for reconciliation and totality underlies the criticism of both the historical and the neo- or post-avant-garde of the 1960s. If there was ambivalence in regard to whether the avant-garde denounced alienation by imitating it or was absorbed by it, the disapproval towards the neo-avant-garde related to movements of the 1960 s goes without saying. The artistic avant-garde of the 1960s was associated by many thinkers with the consumerist culture of late capitalism, of kitsch and of 'anything goes'. In contrast, Lyotard defended postmodernism as a radical artistic movement with a strong political grounding, distinguishing it from a simulating avant-garde and trans-avant-gardism, both products of aesthetic nihilism and of "the realism of money". 36

Recapitulating, a short comment is required regarding the ideological origins of the devaluation of the cultural and artistic movements of the 1960s. The rejection of these movements was founded on an enlightened perception of modernity inextricably linked to normative totality. The fragmentary, anti-holistic modernist and avant-gardist expression, which Habermas conceived as a "desublimated meaning" or a "destructured form", was considered as a negation of culture, an abandonment of utopianism and of Enlightenment premises. ${ }^{37}$ However, the incapability of reformulating the utopian vision so as to incorporate a more tragic sense of the possibilities and limits of human action, as Jane Flax points out, leads thinkers who adopt the enlightened narrative of modernity to a utopian impasse..$^{38}$ On the contrary, a common locus of thinkers who attempted to disconnect utopia and the emancipatory goals of humanity from the Enlightenment project and its totalising components is the diagnosis of disenchantment, of disillusionment due to the loss of faith in human progress connected with modernity. ${ }^{39}$ This approach has its origin in the romantic critique of modernity and leads, through the Frankfurt School, to the movements of the 1960s. ${ }^{40}$ Nevertheless, dissociation from Enlightenment premises does not mark the aban- 
donment of political democracy and human emancipation. ${ }^{41}$ What must be stressed here is that the emergence of alternative forms of art and culture, which put emphasis on the exploration of alterity and subjectivity as well as on the recuperation of buried or censored traditions, derived from the rejection of totalising approaches and of historical perspective as a whole. In this direction, the contribution of the movements of the 1960s was of great importance.

\section{NOTES}

1 Andreas Huyssen, "Mapping the Postmodern", in Andreas Huyssen, After the Great Divide, London: Macmillan, 1988, pp. 188-195. Huyssen borrows the term from Peter Bürger (Theory of the AvantGarde, Minneapolis: University of Minnesota Press, 1984), who includes in the avant-garde Dada, surrealism and the post-revolutionary Russian avant-garde.

2 Huyssen builds his argument on Peter Bürger's view of the historical avant-garde but extends Bürger's argument in regard with the avant-garde to include mainly the American version of postmodernism of the sixties. However, Bürger does not share his opinion. Huyssen, "Mapping", pp. 192-93; Peter Bürger, Theory of the Avant-Garde, University of Minnesota Press: Minneapolis, 1984, pp. 61-63.

3 Andreas Huyssen, “The Search for Tradition”, p. 167.

4 Huyssen reserves the term of genuine avant-garde only for the American movement of the 1960s. However, despite local particularities and without any intention to homogenise its inherent alterity, I believe that the neo avant-garde was a global movement which directly and profoundly challenged society and social institutions.

5 Huyssen, “The Search for Tradition”, pp. 165-173.

6 Bürger, Theory, pp. 35-54, David Harvey, The Condition of Postmodernity, Oxford: Blackwell, 1990, pp. 10-38, 260-283. However, modernism took on multiple perspectivism and relativism as its epistemology not for revealing a unified though complex reality, as David Harvey argues, but as an already fragmented one. See Harvey, The Condition, p. 30.

7 Martin Jay, The Dialectical Imagination, Boston: Little Brown, 1973, pp. 178-182; Theodor W. Adorno, Aesthetic Theory, Minneapolis: University of Minnesota Press, 1997, p. 130.

8 Bürger (Theory, p. 49) adopts the sublation claim, without differentiating it from the demand of merging art into life.

9 Bürger, Theory, pp. 49-50.

10 Huyssen, "The Search for Tradition”, p. 167.

11 Huyssen, "Mapping the Postmodern”, pp. 186-190; Harvey, The Condition, pp. 35-38.

12 Harvey, The Condition, p. 35.

13 Ibid., p. 37.

14 Huyssen, "Mapping the Postmodern", p. 194.

15 The subordination of this heterogeneous set of artistic elaborations under the term postmodernism results from the Enlightenment's tendency to homogenise alterity and difference or, as Judith Butler puts it, from the assumption that the example stands as a symptom and exemplar of the whole, that theories can be substituted for one another, according to the Hegelian trope. See Judith Butler, "Contin- 
gent Foundations: Feminism and the Question of "Postmodernism", in Joan W. Scott and Judith Butler (eds), Feminists Theorize the Political, London: Routledge, 1992, pp. 3-6.

16 However, most theorists have stressed the distinctive diversity of the modernist effort and its particularities.

17 Jürgen Habermas, “Modernity versus Postmodernity”, New German Critique 22 (1981): 3-24.

18 Ibid., p. 8.

19 Ibid., p. 9.

20 Ibid., p. 4.

21 Peter Bürger, "The Significance of the Avant-Garde for Contemporary Aesthetics: A Reply to Jürgen Habermas", New German Critique 22 (1981): 20.

22 Habermas, "Modernity versus Postmodernity", p. 5.

23 Ibid., p. 1.

24 David Harvey makes the same remark. See Harvey, The Condition, p. 38.

25 It is rather ironic that the presentation of this essay is associated with Habermas' award of the Theodor W. Adorno prize. Many readers would probably agree with Anthony Giddens' claim that Habermas strongly reaffirms the principles of Enlightenment without qualification. As Giddens argues, one can recognise without difficulty that Habermas' views have always differed considerably from those of the 'older generation' of the Frankfurt School. Anthony Giddens, "Modernism and Post-modernism", New German Critique 22 (1981): 17.

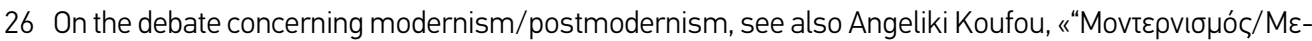

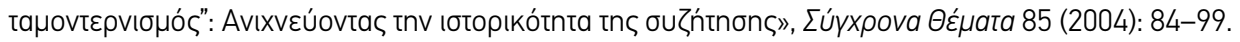

27 Jean-François Lyotard, "Answering the Question: What is Postmodernism?", Afterword to J.-F. Lyotard, The Postmodern Condition: A Report on Knowledge, Manchester: Manchester UP, 1997, pp. 72 $73,77-79,82$. Lyotard reconceptualises the Kantian notion of the sublime, a central theme in romantic philosophy and philosophy of history. On the reconceptualisation of the concept of the sublime, see also Hayden White, "The Politics of Historical Interpretation: Discipline and De-Sublimation", in Hayden White, The Content of the Form, Johns Hopkins UP, 1989, pp. 66-73.

28 On the theoretical differences between Habermas and Lyotard, see Richard Bernstein (ed.), Habermas and Modernity, Cambridge, Mass.: MIT Press, 1985.

29 Lyotard, "Answering the Question", pp. 81-82. The re-evaluation of the sublime serves also his antiholistic premises to the extent that the question of the sublime is also directly involved in the debate concerning totality.

30 According to Lyotard a work can become modern only if it is first postmodern. Consequently, postmodernism is not modernism at its end but in the nascent state. "Answering the Question", p. 79.

31 Adorno, Aesthetic Theory, p. 21.

32 Martin Jay, Marxism and Totality. The Adventures of a Concept from Lukács to Habermas, Berkeley: University of California Press, 1984, p. 261.

33 Ibid., p. 259. See also Jochen Schulte-Sasse, "Foreword", in Bürger, Theory of the Avant Garde, p. xlii.

34 Jay, Marxism, p. 274. 
35 The fact that Andreas Huyssen, who shares with the postmodernists the distrust of a totalising view of history and holistic modernity based on a teleological concept of progress, also endorses the sublation claim renders his approach contradictory. By attributing the sublation claim to the intentions of the avant-garde, Huyssen seems to reintroduce from the back door Habermas' demand for the reconstruction of totality. See Huyssen, "The Search for Tradition", p. 175.

36 Lyotard, "Answering the Question", pp. 75-76.

37 Habermas, "Modernity versus Postmodernity”, pp. 10-11.

38 Martin Jay and Jane Flax, "Forum: On Fredric Jameson, Postmodernism, or, The Cultural Logic of Late Capitalism," History and Theory 32:3 (1993): 308.

39 Lyotard wages a war on totality and considers consensus, but not justice, an outmoded and suspect value. See Lyotard, “Answering The Question”, p. 67, 82.

40 See Lutz Niethammer and Dirk van Laak, Posthistoire: Has History come to an end? London/New York: Verso, 1992.

41 See Chantal Mouffe, "Deconstruction, Pragmatism and the Politics of Democracy", in Chantal Mouffe, Deconstruction and Pragmatism, London/New York: Routledge, 1996. 